Article

\title{
Extra Virgin Olive Oil Phenols Vasodilate Rat Mesenteric Resistance Artery via Phospholipase C (PLC)-Calcium Microdomains-Potassium Channels $\left(\mathrm{BK}_{\mathrm{Ca}}\right)$ Signals
}

\author{
Rossana D'Agostino ${ }^{1}$, Laura Barberio ${ }^{1}$, Mariacarmela Gatto ${ }^{1}$, Teresa Tropea ${ }^{1,2,3}$, Maria De Luca 4 (D) and \\ Maurizio Mandalà 1,5,*(D)
}

1 Department of Biology, Ecology and Earth Sciences, University of Calabria, 87036 Rende, Italy; roxannedag@gmail.com (R.D.); laura.barberio90@gmail.com (L.B.); mariacarmelagatto91@hotmail.it (M.G.); teresa.tropea@manchester.ac.uk (T.T.)

2 Maternal and Fetal Health Research Centre, Division of Developmental Biology and Medicine, Faculty of Biology, Medicine and Health, University of Manchester, Manchester M13 9WL, UK

3 Manchester Academic Health Science Centre, Manchester University NHS Foundation Trust, St. Mary's Hospital, Manchester M13 9WL, UK

4 Department of Nutrition Sciences, University of Alabama at Birmingham, Birmingham, AL 35294, USA; mdeluca2@uab.edu

5 Department of Obstetrics, Gynecology and Reproductive Science, University of Vermont, Burlington, VT 05405, USA

* Correspondence: m.mandala@unical.it

Citation: D'Agostino, R.; Barberio, L.; Gatto, M.; Tropea, T.; De Luca, M.; Mandalà, M. Extra Virgin Olive Oil Phenols Vasodilate Rat Mesenteric Resistance Artery via Phospholipase C (PLC)-Calcium MicrodomainsPotassium Channels $\left(\mathrm{BK}_{\mathrm{Ca}}\right)$ Signals. Biomolecules 2021, 11, 137. https:// doi.org/10.3390/biom11020137

Received: 31 December 2020

Accepted: 18 January 2021

Published: 21 January 2021

Publisher's Note: MDPI stays neutral with regard to jurisdictional claims in published maps and institutional affiliations.

Copyright: (c) 2021 by the authors. Licensee MDPI, Basel, Switzerland. This article is an open access article distributed under the terms and conditions of the Creative Commons Attribution (CC BY) license (https:// creativecommons.org/licenses/by/ $4.0 /)$.

\begin{abstract}
Recent evidence suggests that the reason Extra Virgin Olive Oil (EVOO) lowers blood pressure and reduces the risk of developing hypertension is partly due to minor components of EVOO, such as phenols. However, little is still known about the mechanism(s) through which EVOO phenols mediate anti-hypertensive effects. The aim of the present study was to investigate the mechanisms of action of EVOO phenols on mesenteric resistance arteries. A pressure myograph was used to test the effect of EVOO phenols on isolated mesenteric arteries in the presence of specific inhibitors of: (1) BKca channels (Paxillin, $10^{-5} \mathrm{M}$ ); (2) L-type calcium channels (Verapamil, $10^{-5} \mathrm{M}$ ); (3) Ryanodine receptor, RyR (Ryanodine, $10^{-5} \mathrm{M}$ ); (4) inositol 1,4,5-triphosphate receptor, IP3R, (2-Aminoethyl diphenylborinate, 2-APB, $3 \times 10^{-3} \mathrm{M}$ ); (5) phospholipase C, PLC, (U73122, $\left.10^{-5} \mathrm{M}\right)$, and (6) GPCR-G $\mathrm{\alpha i}_{\mathrm{i}}$ signaling, (Pertussis Toxin, $10^{-5} \mathrm{M}$ ). EVOO phenols induced vasodilation of mesenteric arteries in a dose-dependent manner, and this effect was reduced by pre-incubation with Paxillin, Verapamil, Ryanodine, 2-APB, U73122, and Pertussis Toxin. Our data suggest that EVOO phenol-mediated vasodilation requires activation of BKca channels potentially through a local increase of subcellular calcium microdomains, a pivotal mechanism on the base of artery vasodilation. These findings provide novel mechanistic insights for understanding the vasodilatory properties of EVOO phenols on resistance arteries.
\end{abstract}

Keywords: mesenteric artery; $\mathrm{BK}_{\mathrm{Ca}}$ channels; $\mathrm{Ca}^{2+}$ microdomains; PLC; GPCR-G $\alpha \mathrm{i}$

\section{Introduction}

Systemic arterial hypertension is the most common preventable risk factor for cardiovascular disease (CVD) [1] and is a leading cause of morbidity, disability, and mortality in the world, with an estimated 17.92 million deaths in 2015 [2]. It is well-established that healthy lifestyle choices, such as diet, exercise, and abstinence from smoking, are associated with a lower risk of CVD [3,4]. In this regard, daily consumption of Extra Virgin Olive Oil (EVOO), a key component of the Mediterranean diet [5], is associated with beneficial effects on human health [6] and, in particular, with reduced cardiovascular risk $[7,8]$. Epidemiological and clinical studies indicate that daily intake of at least two tablespoons of EVOO can lower blood pressure, thereby decreasing the risk of developing 
hypertension [9-11]. The chemical composition of EVOO includes two different fractions: the saponifiable fraction, which represents $98-99 \%$ of EVOO and is characterized by a high content of monounsaturated fatty acid (MUFA), and the unsaponifiable fraction which represents $1-2 \%$ of EVOO and includes phenols [12].

The phenolic compounds derive from the secondary metabolism of plants and are chemically characterized by having one or more aromatic rings with one or more hydroxyl groups. The amounts of the phenolic components (150-700 mg/kg) in EVOO depend on many different factors including the cultivars, the degree of maturation, the climate, the production method and the storage [13]. Different groups of phenolic compounds can be found in EVOO, such as secoridoids, phenolic acids, phenolic alcohols, hydroxyisochromans, flavonoids and lignans [14].

Some studies have associated the anti-hypertensive effect of EVOO to its acidic component, especially oleic acid $[15,16]$; however, a growing body of evidence suggests that the phenolic component is the major contributor [17-19] to the biological effects.

Previously, we showed that EVOO phenols exert a vasodilatory effect on rat resistance mesenteric artery (MA) [20], which may underpin the anti-hypertensive properties of EVOO phenols. We demonstrated that EVOO-phenol-induced vasodilation is endotheliumindependent and occurs through activation of the large-conductance calcium-activated potassium $\left(\mathrm{BK}_{\mathrm{ca}}\right.$ ) channels in the vascular smooth muscle cells (VSMCs), but does not involve signaling pathways mediated by nitric oxide (NO)-, prostanoids, or the cyclic nucleotides cAMP and cGMP [20]. The present study will further clarify the mechanism of action of EVOO phenols in MA by investigating the pathways involved in the activation of the $\mathrm{BK}_{\mathrm{ca}}$ channels.

\section{Materials and Methods}

\subsection{Extra Virgin Olive Oil Phenols}

The phenolic extract used in this work is derived from crude EVOO. The liquid/liquid partitioning method was used with methanol/water (80:20) [21]. The use of methanol/water 80:20 $(v / v)$ was reported as an efficient extraction solvent [21] and it is used in the official method of phenolic compounds determination. The extraction was performed through the dispersing device UltraTurrax (IKA®-Werke GmbH \& Co. KG, Staufen, Germany) for $2 \mathrm{~min}$ at $6000 \mathrm{rpm}$. The obtained emulsion was centrifuged at $4000 \mathrm{rpm}$ for $15 \mathrm{~min}$ at room temperature. The hydroalcoholic fraction then was evaporated and later recovered using acetonitrile for residue solubilization and hexane to remove some minor lipid components. The qualitative and quantitative determination of phenolic compounds was accomplished by high performance liquid chromatography (HPLC-UV) [22]. Oleacein (3,4-DHPEA-EDA) is the most abundant phenolic compound in EVOO as well as oleuropein derivatives.

\subsection{Animals}

Male Sprague-Dawley rats $(n=16)$ were used at 18-23 weeks of age. Rats were housed at the University of Calabria under controlled conditions on a $12 \mathrm{~h}$ light/dark cycle; commercial chow and tap water were provided ad libitum. All procedures were conducted in accordance with the European Guidelines for the care and use of laboratory animals (Directive 2010/63/EU) and approved by the Italian Institutional Animal Care (n.295/2016-PR). Animals were euthanized with isoflurane and killed by cervical transection; the abdominal cavity was opened immediately, and a section of the mesentery was excised $5 \mathrm{~cm}$ distal to the pylorus. The mesenteric tissue was placed in a Sylgard-lined Petri dish containing cold $\left(4{ }^{\circ} \mathrm{C}\right)$ HEPES physiological saline solution (PSS) at $\mathrm{pH}=7.4$.

\subsection{Rat Isolated Mesenteric Artery Preparation}

Third-order MA were dissected free from the surrounding adipose and connective tissues and cut into segments of about $3 \mathrm{~mm}$ in length. Vessels were cannulated in the chamber of a small arteriograph (Instrumentation and Model Facility, University of Vermont, Burlington, VT, USA), superfused with HEPES-PSS at $37^{\circ} \mathrm{C}$ and pressurized using 
a pressure-servo system (Living Systems Instrumentation, St. Albans City, VT, USA). Intraluminal diameter was measured using a video dimension analyzer (Living Systems Instrumentation) and recorded on LabView software.

\subsection{Experimental Protocol}

All arteries were pressurized at an intraluminal pressure of $50 \mathrm{mmHg}$ (as it approximates in vivo conditions) and exposed to $\mathrm{K}^{+}$-rich $\left(60 \times 10^{-3} \mathrm{M}\right)$ HEPES-PSS, and Acetylcholine $(10 \mu \mathrm{M})$, to test artery viability and endothelium integrity, respectively. Vessels that did not elicit reproducible responses to either potassium or acetylcholine were excluded from the study. MA were then equilibrated for $30 \mathrm{~min}$ in HEPES-PSS at $37^{\circ} \mathrm{C}$ and pre-constricted with phenylephrine to produce a $40-60 \%$ reduction in lumen diameter [23]. Increasing concentrations $(0.1 \div 10 \mu \mathrm{M})$ of EVOO phenols were tested on pre-constricted $\mathrm{MA}$, and the resulting changes in diameter were recorded once dilation stabilized at each concentration. At the end of each experiment, vessels were treated with the relaxing solution, HEPES-PSS without $\mathrm{Ca}^{2+}$ and containing the phosphodiesterase inhibitor, papaverine $\left(10^{-4} \mathrm{M}\right)$, to induce maximal vasodilation. To investigate molecular mechanism(s) underlying the EVOO phenol-induced vasodilation, a dose-response curve for phenols $(0.1 \div 10 \mu \mathrm{M})$ was tested in arterial segments pre-incubated for $30 \mathrm{~min}$ with one of the following inhibitors, prior to exposure to phenylephrine: (1) Paxillin $(10 \mu \mathrm{M})$ [20], a selective blocker of BK $\mathrm{Ba}_{\text {ca }}$ (2) Verapamil $(10 \mu \mathrm{M})$ [24], a L-type calcium channel blocker; (3) Ryanodyne, $(10 \mu \mathrm{M})$ [25], an inhibitor of Ryanodine receptor (RyR); (4) 2-APB $\left(3 \times 10^{3} \mu \mathrm{M}\right)$ [26], an inhibitor of inositol triphosphate receptor (IP3R); (5) U73122 (10 $\mu \mathrm{M})$ [27], an inhibitor of phospholipase C (PLC); and (6) Pertussis Toxin (10 $\mu \mathrm{M})$ [28], a blocker of the subunit $\mathrm{G}_{\alpha \mathrm{i}}$ of G-protein-coupled receptors (GPCR).

\subsection{Drug and Solutions}

The physiological salt solution HEPES-PSS contained the following (in $\mathrm{mmol} / \mathrm{L}$ ): sodium chloride 141.8 , potassium chloride 4.7 , magnesium sulfate 1.7 , calcium chloride 2.8, potassium phosphate 1.2, HEPES 10.0, EDTA 0.5, and dextrose 5.0. The solution was prepared in deionized water and titrated with sodium hydroxide $(10 \mathrm{M})$ to a physiologic $\mathrm{pH}$ of 7.4.

$\mathrm{K}^{+}$-rich $\left(60 \times 10^{-3} \mathrm{M}\right)$ HEPES-PSS has the same composition as the standard solution, HEPES-PSS, except that $\mathrm{NaCl}$ was replaced by an equimolar concentration of $\mathrm{KCl}$.

Chemicals were purchased from Sigma-Aldrich (Merck KGaA, Darmstadt, Germany), Santa-Cruz (Santa Cruz Biotechnology, Inc., Dallas, TX, USA), Cayman Chemical Co (Cayman Chemical, Ann Arbor, MI, USA). unless otherwise specified. All drugs tested were administered from stock solutions prepared daily, except for EVOO phenols stock solutions that were frozen in small aliquots.

\subsection{Data Analysis and Statistics}

Data are expressed as means \pm Standard Error Media (SEM), where $n$ is both the number of arteries studied and animals used. The vasodilatory effects of EVOO phenols are expressed as percentage of maximal diameter, which was determined in the presence of the relaxing solution. The vasorelaxing efficacy was evaluated as the maximal vasodilatory response (Emax); while the potency was expressed as EC50, calculated as the dilator concentration that caused $50 \%$ of the maximum response. Furthermore, we compared the area under the dose-response curve (AUC) at the different experimental conditions. Statistical analysis was performed with paired Student's $t$-test. $p<0.05$ was considered significant.

\section{Results}

We tested the effect of EVOO phenols $(0.1-10 \mu \mathrm{M})$ on MA pre-constricted with phenylephrine. As shown in Figure 1, EVOO phenols induced significant vasodilation $(p<0.001)$ in a dose-dependent manner, with an Emax of $97.74 \pm 0.63 \%$ and a EC50 of $0.6 \pm 0.04 \mu \mathrm{M}$. Vehicle condition for EVOO phenols (Ethanol) was assessed and did not show any effect. 

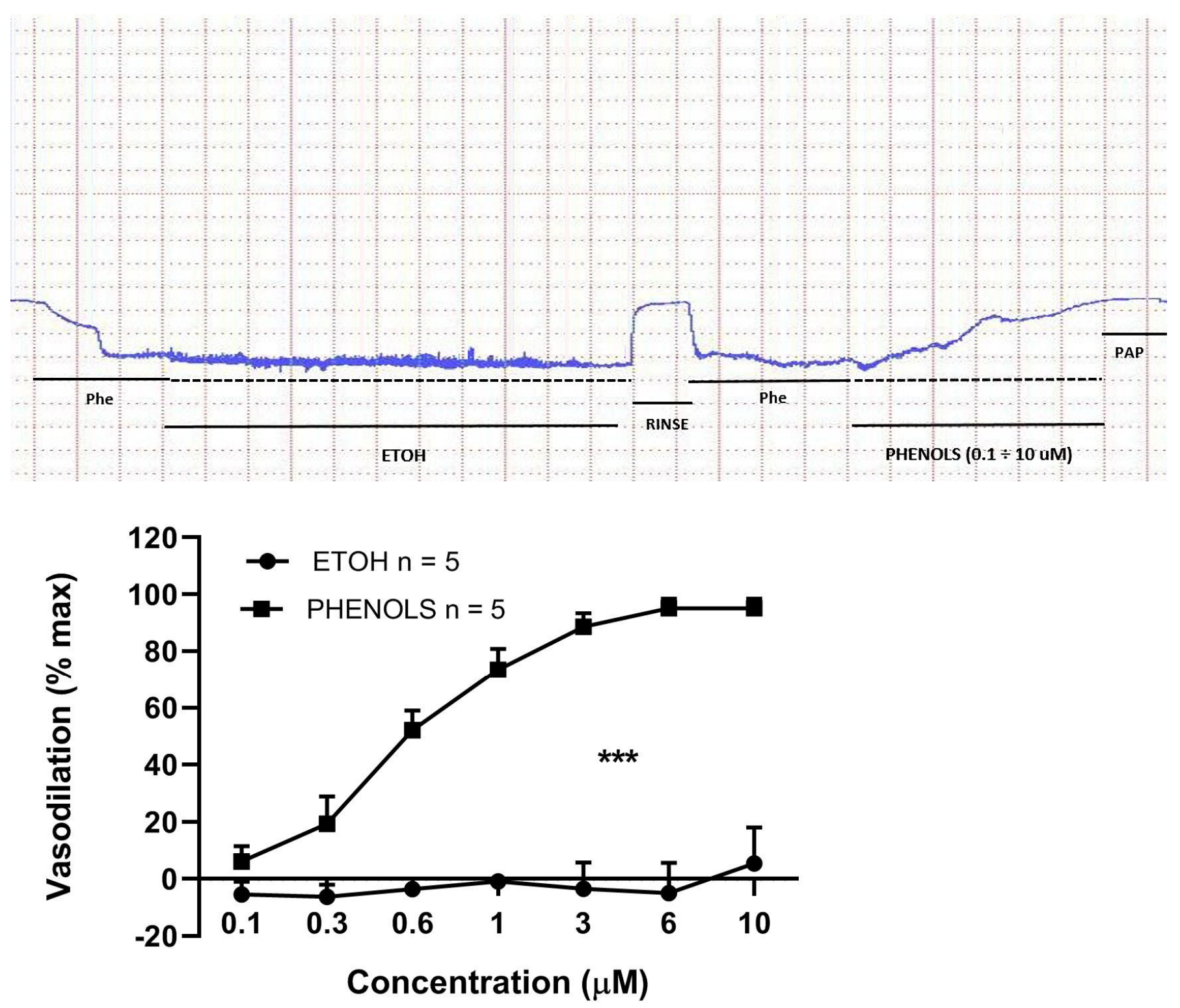

Figure 1. EVOO phenols vasodilation on mesenteric resistance artery. Representative trace showing the effect of Ethanol (EtOH, EVOO phenols vehicle) and EVOO phenols (Phenols, 0.1-10 $\mu \mathrm{M}$ ) in phenylephrine pre-constricted mesenteric resistance artery. HEPES-PSS without $\mathrm{Ca}^{2+}$, containing Papaverine (Pap) was added at the end of each experiment to calculate maximum dilation. Several experiments were done and summarized in the figure, which shows a dose-dependent vasodilation for EVOO phenols but not for EtOH. Data are presented as the mean $\pm \mathrm{SEM}, \mathrm{n}$ (experimental number), *** $p<0.001$ refers to the area under the curve.

To determine the mechanisms by which EVOO phenols induced vasodilation, a doseresponse curve to EVOO phenols was obtained in the presence of the specific inhibitor of $\mathrm{BK}_{\mathrm{ca}}$ channnels, Paxillin $(10 \mu \mathrm{M})$ Figure 2. Pre-incubation with Paxillin shifted the doseresponse curve to the right, with a significant increasing of EC50 $(1 \pm 0.08 \mu \mathrm{M}$ control vs. $5 \pm 0.09 \mu \mathrm{M}$ Paxillin, $p<0.01$ ), and reducing of Emax (98.0 $\pm 5.7 \%$ control vs. $52.4 \pm 13.6 \%$ Paxillin, $p<0.05)$. Interestingly, Paxillin completely abolished EVOO phenol-mediated vasodilation in the dose range of $0.1 \mu \mathrm{M} \div 2 \mu \mathrm{M}$. 


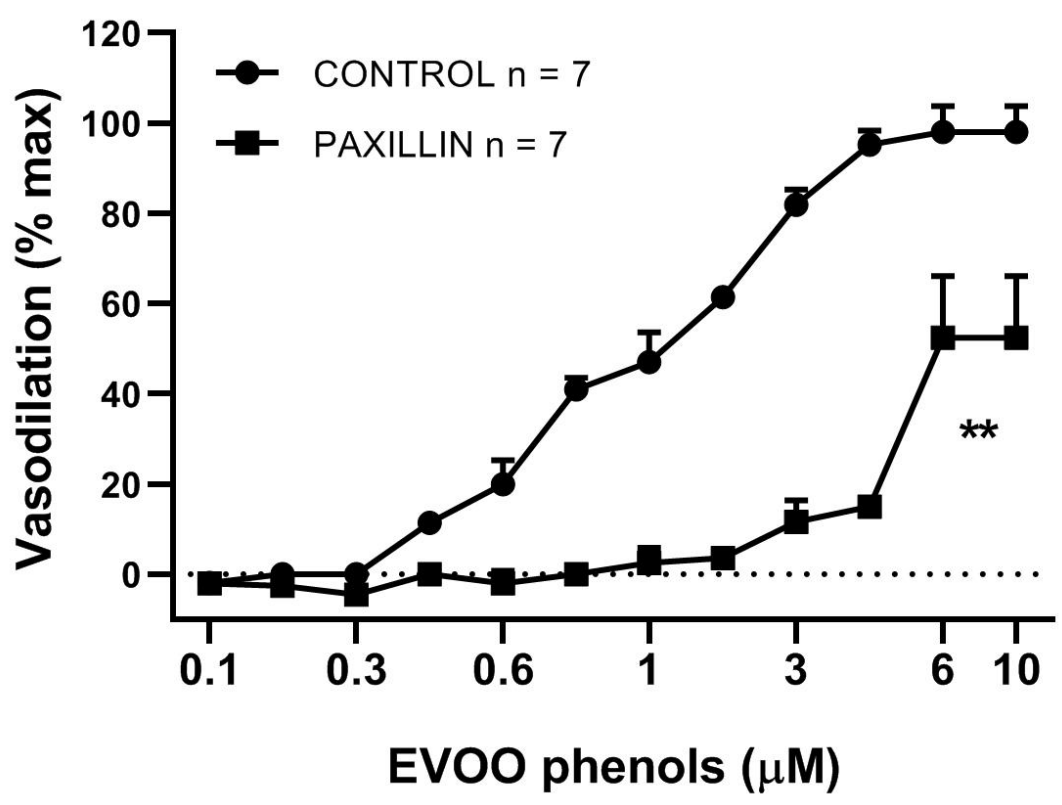

Figure 2. Large-conductance calcium-activated potassium channel blocker reduces EVOO phenolvasodilation. EVOO phenols were tested on mesenteric resistance artery in the absence (control) and in the presence of the selective inhibitor of the large-conductance calcium-activated potassium (BKca) channels, Paxillin $(10 \mu \mathrm{M})$. Data are presented as means \pm SEM, $\mathrm{n}$ (experimental number), ${ }^{* *} p<0.01$ refers to the area under the curve.

To establish whether EVOO phenol-mediated vasodilation was associated with extracellular $\mathrm{Ca}^{2+}$ influx, MA were pre-incubated with the L-type calcium channel blocker, Verapamil $(10 \mu \mathrm{M})$ Figure 3. By blocking extracellular $\mathrm{Ca}^{2+}$ influx, Verapamil induced a rightward shift of the dose-response curve of EVOO phenols, with a significant increase of EC50 $(1 \pm 0.07 \mu \mathrm{M}$ control vs. $4 \pm 0.24 \mu \mathrm{M}$ verapamil, $p<0.05)$, and a significant attenuation of Emax (97.9 $\pm 5.0 \%$ control vs. $64.5 \pm 12.3 \%$ verapamil, $p<0.05)$.

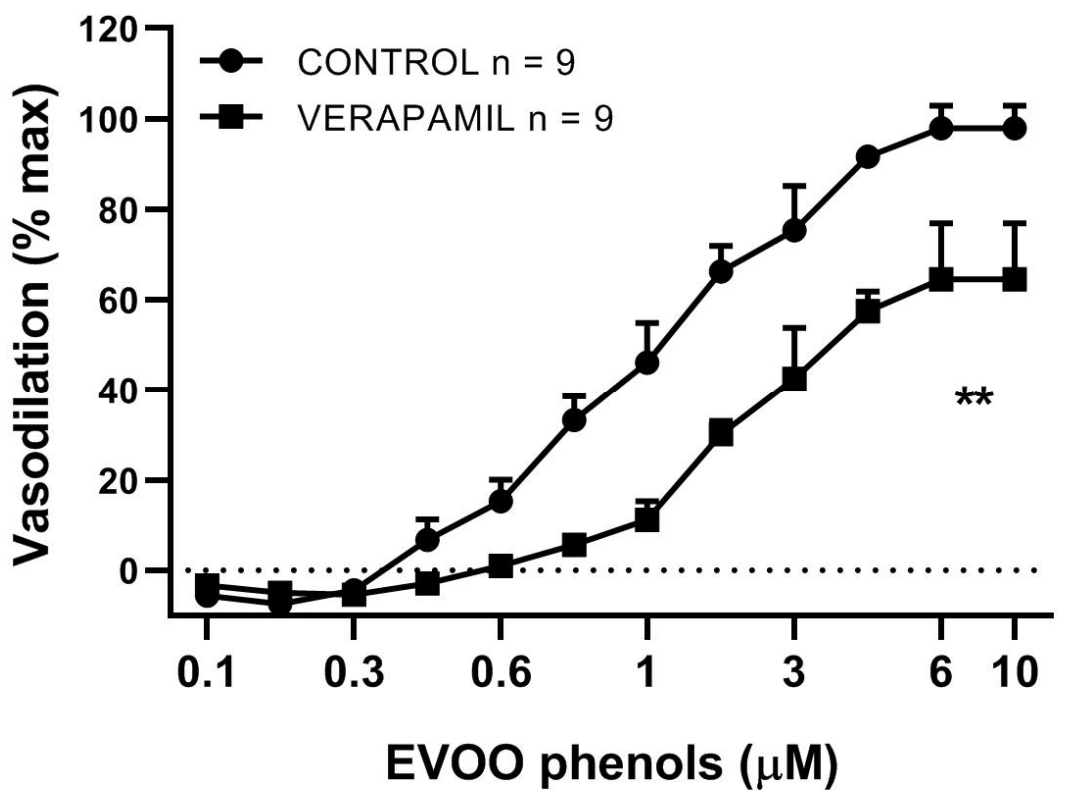

Figure 3. L-type calcium channel blocker attenuates EVOO phenol-vasodilation. EVOO phenols were tested on mesenteric resistance artery in the absence (control) and in the presence of the selective blocker of L-type calcium channel, Verapamil $(10 \mu \mathrm{M})$. Data are presented as means $\pm \mathrm{SEM}$, $\mathrm{n}$ (experimental number), ${ }^{* *} p<0.01$ refers to the area under the curve. 
To assess whether the release of $\mathrm{Ca}^{2+}$ from intracellular stores was also involved in the vasodilation, a set of experiments was performed using two different blockers of intracellular $\mathrm{Ca}^{2+}$ release: Ryanodine $(10 \mu \mathrm{M})$, a potent inhibitor of RyR, and 2-APB $\left(3 \times 10^{3} \mu \mathrm{M}\right)$ an inhibitor of IP3R. Ryanodine decreased Emax $(98.1 \pm 1.53 \%$ control vs. $83.3 \pm 10.9 \%$ ryanodyne, $p>0.05)$, and caused a significant increase of EC50 $(1 \pm 0.05 \mu \mathrm{M}$ control vs. $3 \pm 0.11 \mu \mathrm{M}$ Ryanodine, $p<0.05)$, Figure $4 \mathrm{~A}$. 2-APB did not significantly affect Emax $(98.7 \pm 1.2 \%$ control vs. $87.3 \pm 8.3 \% 2-\mathrm{APB}, p>0.05)$, but significantly potentiated EC50 $(1 \pm 0.08 \mu \mathrm{M}$ control vs. $4 \pm 0.04 \mu \mathrm{M} 2-\mathrm{APB}, p<0.01)$, Figure 4B.

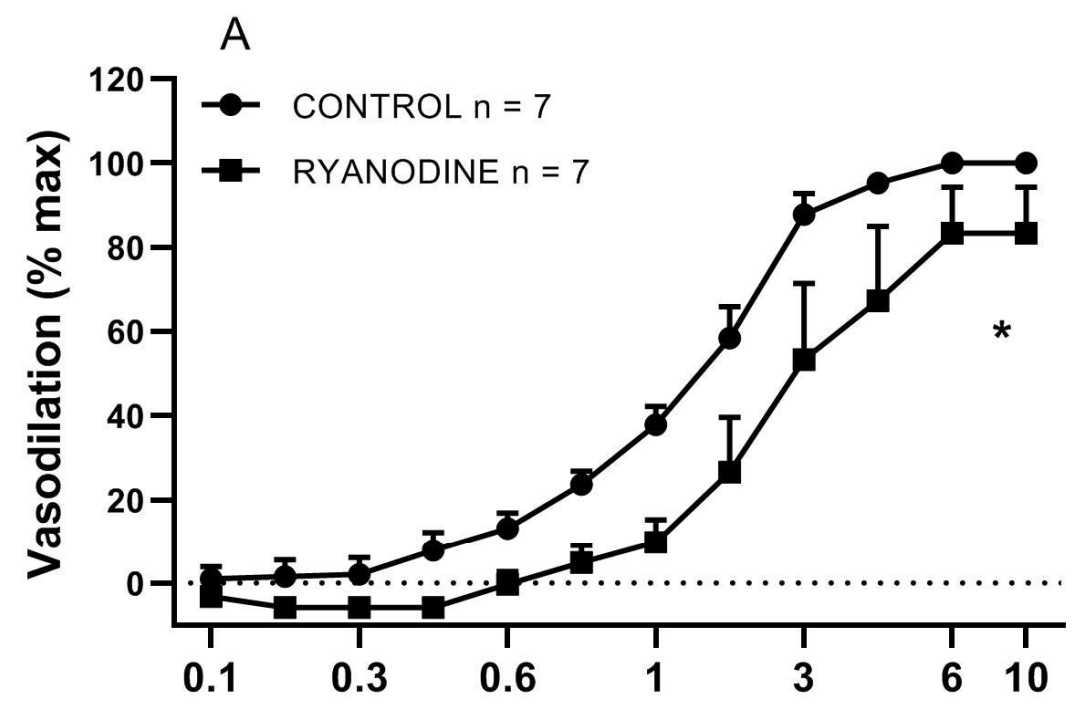

EVOO phenols $(\mu \mathrm{M})$

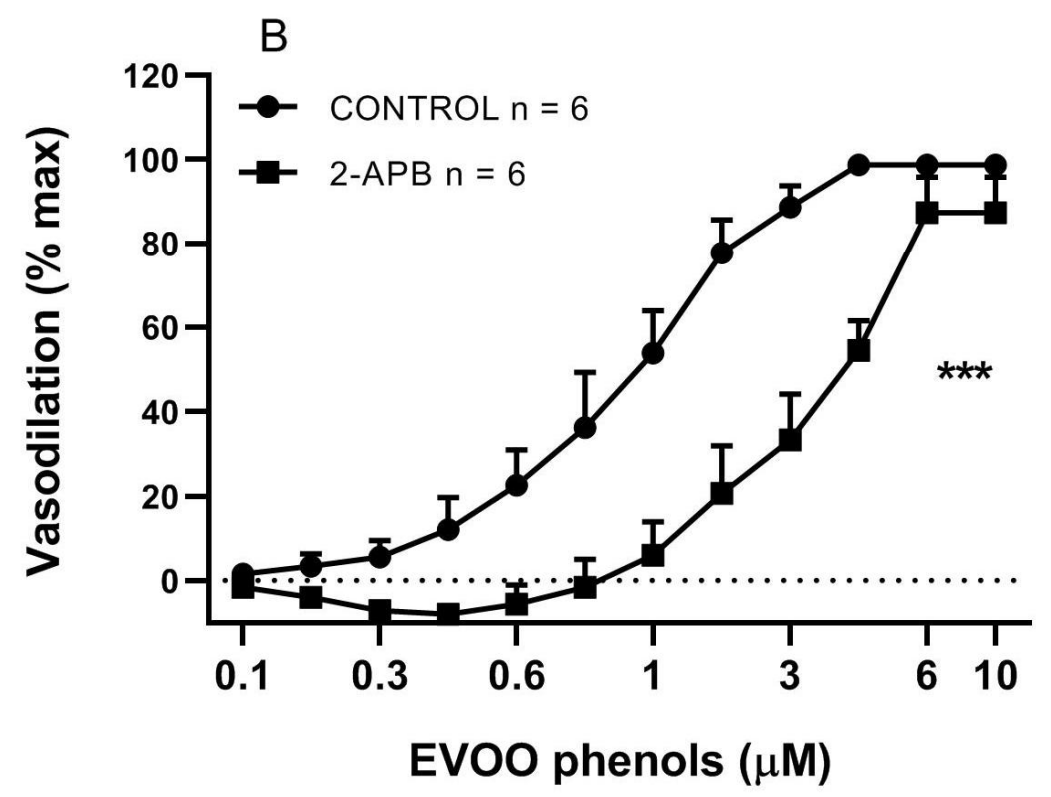

Figure 4. Blockers of intracellular calcium release reduce EVOO phenol-vasodilation. EVOO phenols were tested on mesenteric resistance artery in the absence (control) and in the presence of specific inhibitors of Ryanodine (Ryanodine, $10 \mu \mathrm{M}, \mathrm{A}$ ) and inositol triphosphate receptors $\left(2-\mathrm{APB}, 3 \times 10^{3} \mu \mathrm{M}\right.$, B); Data are reported as means $\pm \mathrm{SEM}, \mathrm{n}$ (experimental number), ${ }^{*} p<0.05,{ }^{* * *} p<0.001$ refer to the area under the curve. 
Furthermore, to confirm the contribution of PLC-initiated in the vasodilatory effect of EVOO phenols, a dose-response curve to EVOO phenols was tested in the presence of the PLC inhibitor U73122 (10 $\mu \mathrm{M})$, which reduced Emax $(98.8 \pm 1.1 \%$ control vs. $27.7 \pm 5,1 \%$ U73122, $p<0.001)$ and increased EC50 (0.5 $\pm 0.06 \mu \mathrm{M}$ control vs. $1 \pm 0.07 \mu \mathrm{M}$ U73122, $p<0.01)$, Figure 5 .

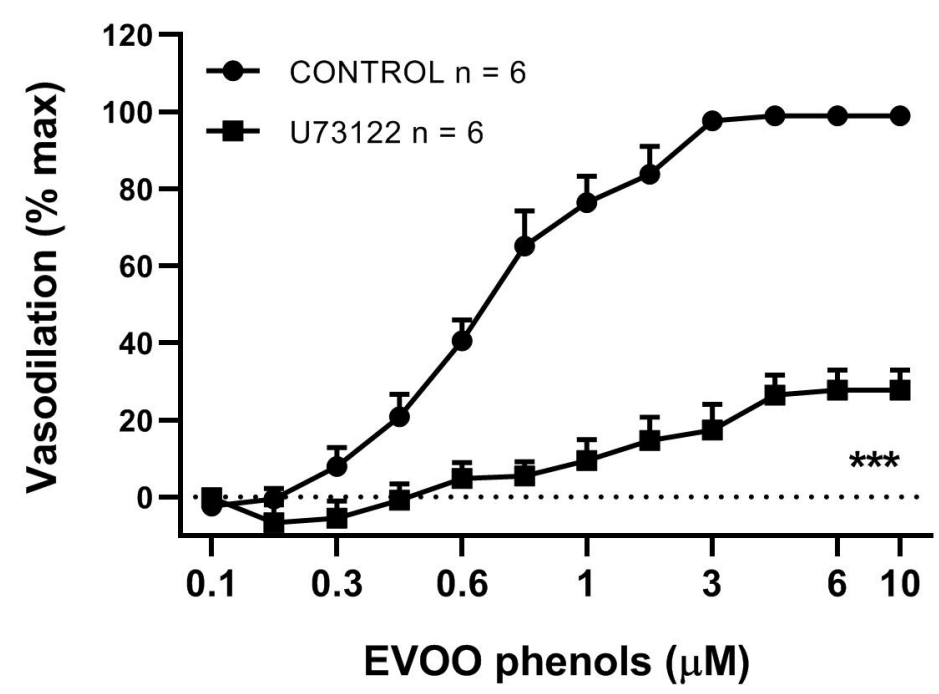

Figure 5. Phospholipase $\mathrm{C}$ blocker inhibits EVOO phenol-vasodilation. EVOO phenols were tested on mesenteric artery in the absence (control) and in the presence of the specific inhibitor of phospholipase C, U73122 $(10 \mu \mathrm{M})$. Data are reported as means $\pm \mathrm{SEM}, \mathrm{n}$ (experimental number), ${ }^{* * *} p<0.001$ refers to the area under the curve.

We investigated also whether activation of GPCR is involved in the EVOO phenolinduced vasodilation. Our data showed that inhibition of the subunit $\mathrm{G}_{\alpha \mathrm{i}}$ of GCPR with Pertussis Toxin $(10 \mu \mathrm{M})$, significantly decreased Emax $(97.6 \pm 1.2 \%$ control vs. $63.4 \pm 9.0 \%$ Pertussis Toxin, $p<0.05$, but did not alter EC50 $(1 \pm 0.06 \mu \mathrm{M}$ control vs. $2 \pm 0.12 \mu \mathrm{M}$ Pertussis Toxin, $p>0.05)$, Figure 6 .

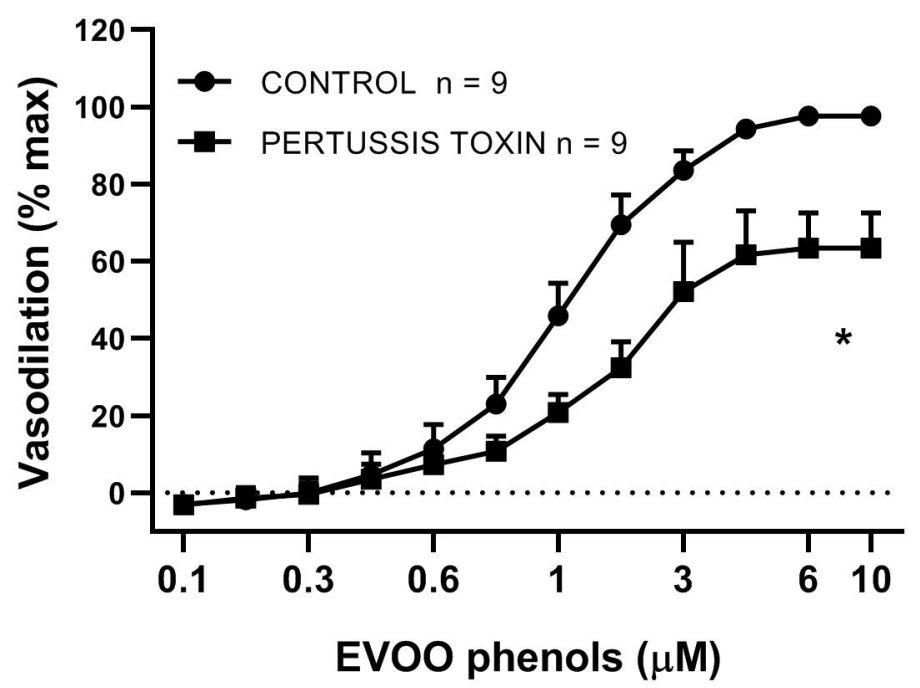

Figure 6. Inactivation of G protein attenuates EVOO phenol-vasodilation. EVOO phenols were tested on mesenteric artery in the absence (control) and in the presence of the specific inhibitor of the GPCR subunit, G $\alpha \mathrm{i}$, Pertussis Toxin $(10 \mu \mathrm{M}$,). Data are reported as means $\pm \mathrm{SEM}, \mathrm{n}$ (experimental number), ${ }^{*} p<0.05$ refers to the area under the curve. 


\section{Discussion}

Our study shows that EVOO phenols dilate resistance MA in a dose-dependent manner. The vasodilation is induced by activation of $\mathrm{BK}_{\mathrm{Ca}}$ channels through an increase of local intracellular $\mathrm{Ca}^{2+}$ level $\left(\mathrm{Ca}^{2+}\right.$ microdomains) as result of influx across the plasma membrane (extracellular $\mathrm{Ca}^{2+}$ ) and release from sarcoplasmic reticulum (SR) $\mathrm{Ca}^{2+}$ store. Furthermore, we showed that EVOO phenols activated PLC, which plays a significant role in the regulation of the $\mathrm{Ca}^{2+}$ microdomains.

Our results confirm the vasodilation that we showed in our previous study in the same type of artery [20]. A similar effect was reported in rat aortic rings [29,30], suggesting that EVOO phenols are vasodilator of both large (conductive) and small (resistance) vessels. Despite recent studies demonstrated the vasodilatory properties of EVOO phenols, the underlying molecular mechanism(s) of vasodilation are not fully known. A canonical mechanism for the vasodilation is the hyperpolarization mediated by potassium channels. We showed that activation of $\mathrm{BK}_{\mathrm{Ca}}$ channels is involved in the EVOO phenol-induced vasodilation of MA. In addition, here we demonstrated that both the release of intracellular $\mathrm{Ca}^{2+}$ from the SR by IP3R and RyR and extracellular $\mathrm{Ca}^{2+}$ influx through the L-type $\mathrm{Ca}^{2+}$ channels are implicated in the EVOO phenols vasodilation. Taken together, our results suggest that EVOO phenols activate $\mathrm{BK}_{\mathrm{Ca}}$ channels potentially through an increase in intracellular localized $\mathrm{Ca}^{2+}$ transients. In agreement with other studies, our data suggest that EVOO phenols may lead to the increase of local $\mathrm{Ca}^{2+}$ microdomains which, in turn, are responsible for the vasodilatory effect on mesenteric resistance arteries. In muscle cells, the release of $\mathrm{Ca}^{2+}$, in the form of $\mathrm{Ca}^{2+}$ sparks, induced by RyR in the sub-plasma membrane of the SR, controls the activity of the nearby $\mathrm{BK}_{\mathrm{Ca}}$ channels in many resistance arteries [31-34]. On the other hand, $\mathrm{Ca}^{2+}$ influx through the L-type $\mathrm{Ca}^{2+}$ channels has been shown to activate $\mathrm{BK}_{\mathrm{Ca}}$ channels in different types of vessels, including hamster and mouse cremaster arterioles [35,36], rat mesenteric arteries [37] and mouse mesenteric arteries [38]. In striated muscle resistance arteries, both $\mathrm{Ca}^{2+}$ influx through L-type channels and RyR-based $\mathrm{Ca}^{2+}$ sparks, contribute to activation of $\mathrm{BK}_{\mathrm{Ca}}$ channels $[35,36]$. Studies in VSMCs from mouse MA [38] have shown that $\mathrm{Ca}^{2+}$ influx through L-type $\mathrm{Ca}^{2+}$ channels can directly activate $\mathrm{BK}_{\mathrm{Ca}}$ channels. Furthermore, it has been demonstrated that, in vascular smooth muscle cells, $\mathrm{BK}_{\mathrm{Ca}}$ and L-type $\mathrm{Ca}^{2+}$ channels can directly interact forming complexes that are accumulated in caveolae by the interaction of caveolin-1, thereby regulating spatiotemporal $\mathrm{Ca}^{2+}$ dynamics including the negative feedback, to control the arterial excitability and contractility [38].

Furthermore, we demonstrated that EVOO phenols indirectly activated PLC which plays a crucial role in the generation of inositol triphosphate (IP3) a specific agonist of the abundant SR Ca ${ }^{2+}$ channels IP3R. Our results showed that EVOO phenols-PLC activation occurred through the subunit Gai of GPCR since its inhibition by the specific inhibitor pertussin toxin decreased EVOO phenols vasodilation. This can be explained by the fact that $\mathrm{G} \alpha \mathrm{i}$ activation inhibits cAMP-PKA signaling which exerts its inhibitory effects by phosphorylation of both PLC and IP3R, thus limiting the $\mathrm{Ca}^{2+}$ mobilization [39].

The involvement of the individual factors PLC, IP3R, RyR and G protein has been reported also in other studies of vasodilation mechanism [40-45].

In conclusion, the present study contributes to understand the molecular mechanisms of the EVOO phenol-induced vasodilation of MA as summarized in Figure 7. Moreover, it shows, for the first time, that EVOO phenols lower vascular resistance through the activation of the subcellular $\mathrm{Ca}^{2+}$ microdomains-BK $\mathrm{Ca}_{\mathrm{a}}$ signal. 


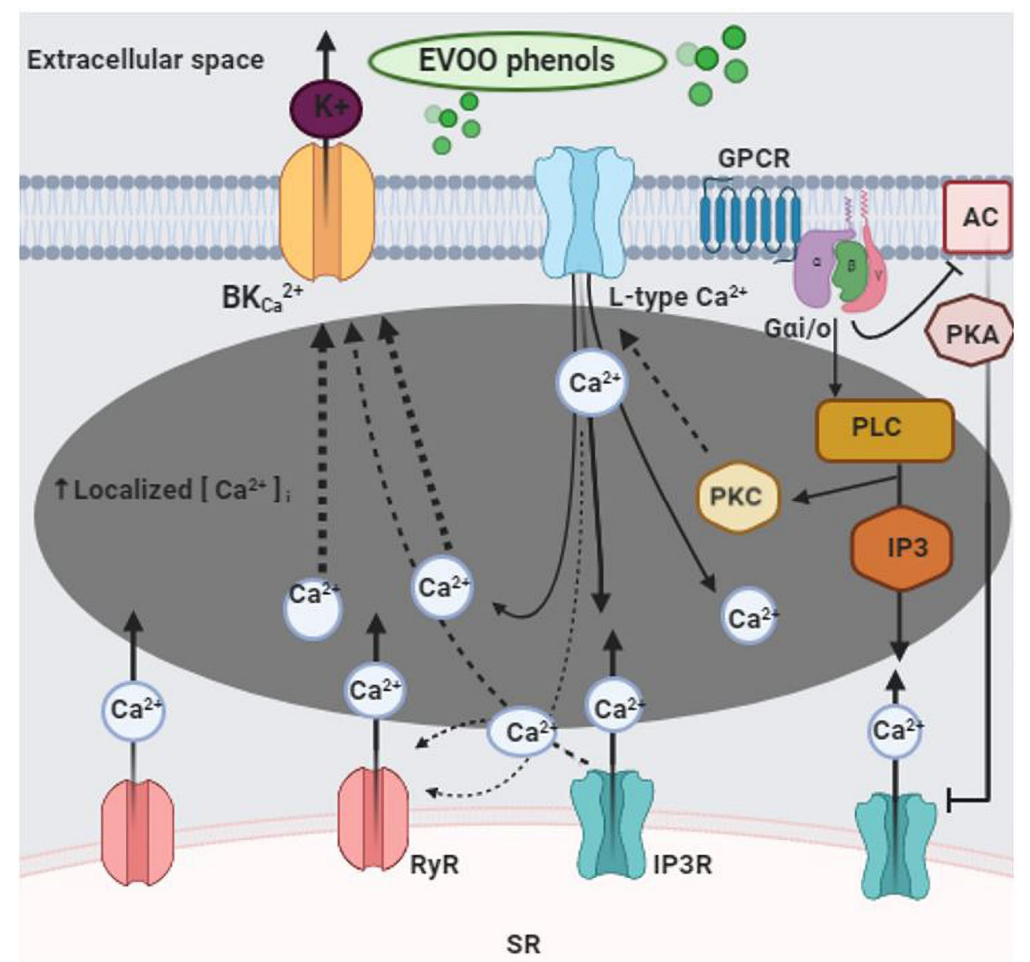

Figure 7. Mechanisms of action of EVOO phenols on vascular smooth muscle cells in mesenteric resistance arteries. EVOO phenols act on the smooth muscle cells of mesenteric resistance artery and trigger intracellular $\mathrm{Ca}^{2+}$ signaling. In detail, EVOO phenols activate L-type $\mathrm{Ca}^{2+}$ channels and GPCR-G $\alpha$ i-mediated-PLC pathways, which in turn activate the sarcoplasmic reticulum channels, RyR and IP3R. The overall result of these signaling cascade is the production of localized sites with high concentrations of $\mathrm{Ca}^{2+}$, named $\mathrm{Ca}^{2+}$ microdomains, which determine the activation of the BKca channels. Calcium Channels L-type (L-type $\mathrm{Ca}^{2+}$ ), large-conductance calcium-activated potassium channels (BKca), inositol 1,4,5-triphosphate receptor (IP3R), phospholipase C (PLC), Ryanodine receptor (RyR), G $\alpha$ i subunit of $G$ protein-coupled receptor (GPCR-G $\alpha i$ ), protein kinase C (PKC), adenylate cyclase (AC), protein kinase A (PKA), sarcoplasmic reticulum (SR).

Author Contributions: Conceptualization, M.M. and R.D.; Methodology, R.D.; Formal Analysis, R.D. and L.B.; Investigation, R.D., L.B., M.G.; Resources, M.M.; Data Curation, R.D.; Writing R.D. and M.M.-Original Draft Preparation, R.D. and M.M.; Writing-Review \& Editing, T.T. and M.D.L.; Supervision, M.M. All authors have read and agreed to the published version of the manuscript.

Funding: This research received no external funding.

Institutional Review Board Statement: The study was conducted according to the guidelines of the Declaration of Helsinki and approved by the Italian Institutional Animal Care (n. 295/2016-PR of 24 March 2016).

Acknowledgments: The authors would like to thank "Agrocalabria srl" 88050 Belcastro (CZ), Italy, for providing the EVOO. We also thank Antonio Procopio and Sonia Bonacci, Dept. of Health Science, University “Magna Græcia” 88100 Catanzaro, Italy, to isolate the EVOO phenols.

Conflicts of Interest: The authors declare no conflict of interest.

\section{References}

1. Oparil, S.; Acelajado, M.C.; Bakris, G.L.; Berlowitz, D.R.; Cífková, R.; Dominiczak, A.F.; Grassi, G.; Jordan, J.; Poulter, N.R.; Rodgers, A.; et al. Hypertension. Nat. Rev. Dis Primers 2018, 4. [CrossRef] [PubMed]

2. Roth, G.A.; Johnson, C.; Abajobir, A.; Abd-Allah, F.; Abera, S.F.; Abyu, G.; Ahmed, M.; Aksut, B.; Alam, T.; Alam, K.; et al. Global, Regional, and National Burden of Cardiovascular Diseases for 10 Causes, 1990 to 2015. J. Am. Coll. Cardiol. 2017, 70, 1-25. [CrossRef] [PubMed] 
3. Stampfer, M.J.; Hu, F.B.; Manson, J.E.; Rimm, E.B.; Willett, W.C. Primary prevention of coronary heartdisease in women through diet and lifestyle. N. Engl. J. Med. 2000, 343, 16-22. [CrossRef] [PubMed]

4. Knoops, K.T.; de Groot, L.C.; Kromhout, D.; Perrin, A.E.; Moreiras-Varela, O.; Menotti, A.; van Staveren, W.A. Mediterranean diet, lifestyle factors, and 10-year mortality in elderly European men and women: The HALE project. JAMA 2004, 292, 1433-1439. [CrossRef]

5. Gaforio, J.J.; Visioli, F.; Alarcón-de-la-Lastra, C.; Castañer, O.; Delgado-Rodríguez, M.; Fitó, M.; Hernández, A.F.; Huertas, J.R.; Martínez-González, M.A.; Menendez, J.A. Virgin Olive Oil and Health: Summary of the III International Conference on Virgin Olive Oil and Health Consensus Report, JAEN (Spain) 2018. Nutrients 2019, 11, 2039. [CrossRef]

6. Alarcon de la Lastra, G.; Barranco, M.D.; Motilva, V.; Herrerias, J.M. Mediterranean diet and health: Biological importance of olive oil. Curr. Pharm. Des. 2001, 7, 933-950. [CrossRef]

7. Carluccio, M.A.; Massaro, M.; Scoditti, E.; De Caterina, R. Vasculoprotective potential of olive oil components. Mol. Nutr. Food Res. 2007, 51, 1225-1234. [CrossRef]

8. Nocella, C.; Cammisotto, V.; Fianchini, L.; D’Amico, A.; Novo, M.; Castellani, V.; Stefanini, L.; Violi, F.; Carnevale, R. Extra Virgin Olive Oil and Cardiovascular Diseases: Benefits for Human Health. Endocr. Metab. Immune Disord. Drug Targets. 2018, 18, 4-13. [CrossRef]

9. Perona, J.S.; Canizares, J.; Montero, E.; Sanchez-Dominguez, J.M.; Catala, A.; Ruiz-Gutierrez, V. Virgin olive oil reduces blood pressure in hypertensive elderly subjects. Clin. Nutr. 2004, 23, 1113-1121. [CrossRef]

10. Estruch, R.; Ros, E.; Salas-Salvado, J.; Covas, M.I.; Corella, D.; Aros, F.; Gomez-Gracia, E.; Ruiz-Gutierrez, V.; Fiol, M.; Lapetra, J.; et al. Primary prevention of cardiovascular disease with a Mediterranean diet. N. Engl. J. Med. 2013, 368, 1279-1290. [CrossRef]

11. Domenech, M.; Roman, P.; Lapetra, J.; Garcia de la Corte, F.J.; Sala-Vila, A.; de la Torre, R.; Corella, D.; Salas-Salvado, J.; Ruiz-Gutierrez, V.; Lamuela-Raventos, R.M.; et al. Mediterranean diet reduces 24-hour ambulatory blood pressure, blood glucose, and lipids: One-year randomized, clinical trial. Hypertension 2014, 64, 69-76. [CrossRef] [PubMed]

12. Boskou, D.; Tsimidou, M.; Blekas, G. Polar Phenolic Compounds. In Olive Oil: Chemistry and Technology, 2nd ed.; The American Oil Chemists' Society: Urbana, IL, USA, 2006.

13. Servili, M.; Sordini, B.; Esposto, S.; Urbani, S.; Veneziani, G.; Di Maio, I.; Selvaggini, R.; Taticchi, A. Biological Activities of Phenolic Compounds of Extra Virgin Olive Oil. Antioxidants 2013, 3, 1-23. [CrossRef] [PubMed]

14. Romani, A.; Ieri, F.; Urciuoli, S.; Noce, A.; Marrone, G.; Nediani, C.; Bernini, R. Health Effects of Phenolic Compounds Found in Extra-Virgin Olive Oil, By-Products, and Leaf of Olea europaea L. Nutrients 2019, 11, 1776. [CrossRef] [PubMed]

15. Alemany, R.; Terés, S.; Baamonde, C.; Benet, M.; Vögler, O.; Escribá, P.V. 2-Hydroxyoleic Acid: A new Hypotensive Molecule. Hypertension 2004, 43, 249-254. [CrossRef] [PubMed]

16. Terés, S.; Barceló-Coblijn, G.; Benet, M.; Alvarez, R.; Bressani, R.; Halver, J.E.; Escriba, P.V. Oleic acid content is responsible for the reduction in blood pressure induced by olive oil. Proc. Natl Acad. Sci. USA 2008, 105, 13811-13816. [CrossRef]

17. Konstantinidou, V.; Covas, M.I.; Munoz-Aguayo, D.; Khymenets, O.; de la Torre, R.; Saez, G.; Tormos Mdel, C.; Toledo, E.; Marti, A.; Ruiz-Gutierrez, V.; et al. In vivo nutrigenomic effects of virgin olive oil polyphenols within the frame of the Mediterranean diet: A randomized controlled trial. FASEB J. 2010, 24, 2546-2557. [CrossRef]

18. Fito, M.; Cladellas, M.; de la Torre, R.; Marti, J.; Alcantara, M.; Pujadas-Bastardes, M.; Marrugat, J.; Bruguera, J.; Lopez-Sabater, M.C.; Vila, J.; et al. Antioxidant effect of virgin olive oil in patients with stable coronary heart disease: A randomized, crossover, controlled, clinical trial. Atherosclerosis 2005, 181, 149-158. [CrossRef]

19. Moreno-Luna, R.; Munoz-Hernandez, R.; Miranda, M.L.; Costa, A.F.; Jimenez-Jimenez, L.; Vallejo-Vaz, A.J.; Muriana, F.J.; Villar, J.; Stiefel, P. Olive oil polyphenols decrease blood pressure and improve endothelial function in young women with mild hypertension. Am. J. Hypertens. 2012, 25, 1299-1304. [CrossRef]

20. D'Agostino, R.; Barberio, L.; Gatto, M.; Muzzalupo, I.; Mandalà, M. Extra Virgin Olive Oil Phenols Dilate the Rat Mesenteric Artery by Activation of BKCa2+ Channels in Smooth Muscle Cells. Molecules 2020, 25, 2601. [CrossRef]

21. Montedoro, G.; Servili, M.; Baldioli, M.; Miniati, E. Simple and hydrolyzable phenolic compounds in virgin olive oil. 1. Their extraction, separation, and quantitative and semiquantitative evaluation by HPLC. J. Agr. Food Chem. 1992, 40, 1571-1576. [CrossRef]

22. Mateos, R.; Espartero, J.L.; Trujillo, M.; Ríos, J.J.; León-Camacho, M.; Alcudia, F.; Cert, A. Determination of phenols, flavones, and lignans in virgin olive oils by solid-phase extraction and high-performance liquid chromatography with diode array ultraviolet detection. J. Agr. Food Chem. 2001, 49, 2185-2192. [CrossRef] [PubMed]

23. Colton, I.; Mandalà, M.; Morton, J.; Davidge, S.T.; Osol, G. Influence of Constriction, Wall Tension, Smooth Muscle Activation and Cellular Deformation on Rat Resistance Artery Vasodilator Reactivity. Cell Physiol. Biochem. 2012, 29, 883-892. [CrossRef] [PubMed]

24. Takase, H.; Moreau, P.; Küng, C.F.; Nava, E.; Lüscher, T.F. Antihypertensive therapy prevents endothelial dysfunction in chronic nitric oxide deficiency. Effect of verapamil and trandolapril. Hypertension 1996, 27, 25-31. [CrossRef] [PubMed]

25. Krishnamoorthy, G.; Sonkusare, S.K.; Heppner, T.J.; Nelson, M.T. Opposing roles of smooth muscle BK channels and ryanodine receptors in the regulation of nerve-evoked constriction of mesenteric resistance arteries. Am. J. Physiol. Heart Circ. Physiol. 2014, 306, H981-H988. [CrossRef] [PubMed] 
26. Sukhanova, K.Y.; Thugorka, O.M.; Bouryi, V.A.; Harhun, M.I.; Gordienko, D.V. Mechanisms of the sarcoplasmic reticulum Ca2+ release induced by P2X receptor activation in mesenteric artery myocytes. Pharmacol. Rep. 2014, 66, 363-372. [CrossRef]

27. Wei, R.; Lunn, S.E.; Tam, R.; Gust, S.L.; Classen, B.; Kerr, P.M.; Plane, F. Vasoconstrictor stimulus determines the functional contribution of myoendothelial feedback to mesenteric arterial tone. J Physiol. 2018, 596, 1181-1197. [CrossRef]

28. Zhang, W.; Feng, X.; Zhang, Y.; Sun, M.; Li, L.; Gao, Q.; Tang, J.; Zhang, P.; Lv, J.; Zhou, X.; et al. Prenatal hypoxia inhibited propionate-evoked BK channels of mesenteric artery smooth muscle cells in offspring. J. Cell Mol. Med. 2020, 24, 3192-3202. [CrossRef]

29. Benkhalti, F.; Legssyer, A.; Gómez, P.; Paz, E.; Lopez-Miranda, J.; Jiménez, F.P.; El Boustani, E.S. Effects of virgin olive oil phenolic compounds on LDL oxidation and vasorelaxation activity. Therapies 2003, 58, 133-137. [CrossRef]

30. Segade, M.; Bermejo, R.; Monteiro-Silva, F.; Paiva-Martins, F.; Gil-Longo, J.; Campos-Toimil, M. Involvement of endothelium in the vasorelaxant effects of 3,4-DHPEA-EA and 3,4-DHPEA-EDA, two major functional bioactives in olive oil. J. Funct. Foods 2016, 23, 637-646. [CrossRef]

31. Koide, M.; Nystoriak, M.A.; Krishnamoorthy, G.; O'Connor, K.P.; Bonev, A.D.; Nelson, M.T.; Wellman, G.C. Reduced Ca2+ Spark Activity after Subarachnoid Hemorrhage Disables BK Channel Control of Cerebral Artery Tone. Br. J. Pharmacol. 2010, 31, 3-16. [CrossRef]

32. Fan, G.; Cui, Y.; Gollasch, M.; Kassmann, M. Elementary calcium signaling in arterial smooth muscle. Channels 2019, 13, 505-519. [CrossRef] [PubMed]

33. Khavandi, K.; Baylie, R.A.; Sugden, S.A.; Ahmed, M.; Csato, V.; Eaton, P.; Hill-Eubanks, D.C.; Bonev, A.D.; Nelson, M.T.; Greenstein, A.S. Pressure-induced oxidative activation of PKG enables vasoregulation by $\mathrm{Ca}^{2+}$ sparks and BK channels. Sci. Signal. 2016, 9. [CrossRef] [PubMed]

34. Dabertrand, F.; Nelson, M.T.; Brayden, J.E. Acidosis dilates brain parenchymal arterioles by conversion of calcium waves to sparks to activate BK channels. Circ. Res. 2012, 110, 285-294. [CrossRef] [PubMed]

35. Westcott, E.B.; Goodwin, E.L.; Segal, S.S.; Jackson, W.F. Function and expression of ryanodine receptors and inositol 1,4,5trisphosphate receptors in smooth muscle cells of murine feed arteries and arterioles. J. Physiol. 2012, 590, 1849-1869. [CrossRef]

36. Westcott, E.B.; Jackson, W.F. Heterogeneous function of ryanodine receptors, but not IP3 receptors, in hamster cremaster muscle feed arteries and arterioles. Am. J. Physiol. Heart Circ. Physiol. 2011, 300, H1616-H1630. [CrossRef]

37. Zhang, Y.; Chen, Y.; Xu, Z.; Wu, Y.; Zhang, Y.; Shi, L. Chronic exercise mediates epigenetic suppression of L-type Ca ${ }^{2+}$ channel and BKCa channel in mesenteric arteries of hypertensive rats. J. Hypertens. 2020, 38, 1763-1776. [CrossRef]

38. Suzuki, Y.; Yamamura, H.; Ohya, S.; Imaizumi, Y. Caveolin-1 facilitates the direct coupling between large conductance Ca2+activated $\mathrm{K}+(\mathrm{BKCa})$ and Cav1.2 $\mathrm{Ca} 2+$ channels and their clustering to regulate membrane excitability in vascular myocytes. J. Biol. Chem. 2013, 288, 36750-36761. [CrossRef]

39. Huang, J.; Zhou, H.; Mahavadi, S.; Sriwai, W.; Murthy, K.S. Inhibition of Gaq-dependent PLC-beta1 activity by PKG and PKA is mediated by phosphorylation of RGS4 and GRK2. Am. J. Physiol. Cell Physiol. 2007, 292, C200-C208. [CrossRef]

40. Al Suleimani, Y.M.; Hiley, C.R. Mechanisms of vasorelaxation induced by oleoylethanolamide in the rat small mesenteric artery. Eur. J. Pharmacol. 2013, 702, 1-11. [CrossRef]

41. Ruisanchez, É.; Dancs, P.; Kerék, M.; Németh, T.; Faragó, B.; Balogh, A.; Patil, R.; Jennings, B.L.; Liliom, K.; Malik, K.U.; et al. Lysophosphatidic acid induces vasodilation mediated by LPA1 receptors, phospholipase $\mathrm{C}$, and endothelial nitric oxide synthase. FASEB J. 2014, 28, 880-890. [CrossRef]

42. Heathcote, H.R.; Lee, M.D.; Zhang, X.; Saunter, C.D.; Wilson, C.; McCarron, J.G. Endothelial TRPV4 channels modulate vascular tone by Ca2+-induced Ca2+ release at inositol 1,4,5-trisphosphate receptors. Br. J. Pharmacol. 2019, 176, 3297-3317. [CrossRef] [PubMed]

43. Yuan, Q.; Yang, J.; Santulli, G.; Reiken, S.R.; Wronska, A.; Kim, M.M.; Osborne, B.W.; Lacampagne, A.; Yin, Y.; Marks, A.R. Maintenance of normal blood pressure is dependent on IP3R1-mediated regulation of eNOS. Proc. Natl. Acad. Sci. USA 2016, 113, 8532-8537. [CrossRef] [PubMed]

44. Knot, H.J.; Standen, N.B.; Nelson, M.T. Ryanodine receptors regulate arterial diameter and wall $\left[\mathrm{Ca}^{2+}\right]$ in cerebral arteries of rat via $\mathrm{Ca}^{2+}$-dependent $\mathrm{K}^{+}$channels. J. Physiol. 1998, 508, 211-221. [CrossRef] [PubMed]

45. Strassheim, D.; Karoor, V.; Stenmark, K.; Verin, A.; Gerasimovskaya, E. A current view of G protein-coupled receptor - mediated signaling in pulmonary hypertension: Finding opportunities for therapeutic intervention. Vessel. Plus 2018, 2, 29. [CrossRef] [PubMed] 